[38〕アクリロニトリル重合体に対するジメチルスル

ホキサイド系混合溶媒の溶解力

(1960 年 10 月 18 日受理)

\author{
高 橋 正 夫*
}

\begin{abstract}
要旨 ジメチルスルホキサイド(DMSO) と種々の混合成分上よりなる混合溶媒を検即し，次のよう な一般的傾向庄認めた。すなわち DMSOはすぐれた良溶媒であるために, 混合成分はその溶解状態を変化さ せ，あるい:希积剤としての役割を果すなどの効果をもたらすが、溶解性を向上させるような効果はもたらし えない。したがって単独で溶解力のある成分との混合系の溶解温度は, 両成分の溶解温度の中間の值を示し, 単独で溶解力のない成分上の混合系では, 混合成分の性犋に応じた溶解限界組成が存在する。

混合溶媒を用いた浱㫗溶液の粘度は, DMSO 単独の場合よりも低粘度を示す場合が多く,このような采で は粘度安定性が低下し, 非ニュートン性も小さくなっている。さらに溶解力が小さくな机ば粘度上年, 非ニュ 一トン性つ増大などがみられる。
\end{abstract}

\section{1. 楮言}

DMSO はアクリル重合体の良溶媒の一つである。 DMSO との混合溶媒は，DMSO の溶解性が著しく良好 なので, 溶解力を向上させるという点ではあまり期待さ れないと考えられるが，種々の変わった特性を与えるべ き添加剤的効果を生ずることは可能と思われる。片山 ら1は，DMSO-アセトニトリル混合溶媒を用いた際に， 粘度が著しく低下することを見出している。またこれれ ら溶液の紡采結果についても若干の結果を報告してい る。筆者は DMSO 采混合溶媒の若干の采における溶解 性を溶解温度, 膨潤度, すれれ応力による粘度变化, 粘度 およびその安定性などから比較検討した。

\section{2. 実験方法}

\section{1 溶解温度の測定法}

既報”の方法と同し方法を用いた。

\section{2 湿厚溶液の粘度测定法}

島津製作所製ユニパーサルレオメータ(外筒回転形 Couette 型粘度計）を用いて one bob method によっ て測定した。外筒の半径 $R_{2}$ と内筒の半径 $R_{1}$ の比 $\alpha=$ $R_{2} / R_{1}$ は 1.053 である。ずれ速度 $f(S)$ は次式で表わされ $ろ^{2)}$ 。

$$
\begin{aligned}
& \frac{f(S)}{S}=\varphi_{a}[1+\Delta S] \\
& \Delta S=k_{1}\left(\frac{d \log \varphi_{a}}{d \log S}\right)+k_{2}\left(\frac{d \log \varphi_{a}}{d \log S}\right)^{2} \\
& \text { 流動率 } \varphi_{a}=\left(\frac{2}{1}-\frac{1}{\alpha^{2}}\right)\left(\frac{\Omega}{S}\right)
\end{aligned}
$$

* 東洋レーヨン株式会社中央研究所 (大津市石山北大路官之内
ただし $S$ はずれの応力, $k_{1}$ および $k_{2}$ は装置定数で 0.128 および $0.0397, \Omega$ は外筒の角速度である。」S は非二ュ 一トン性の尺度であり,またずれ速度 $\rightarrow 0$ のときの $\gamma_{0}$ を zero shear viscosity として比較した。

\section{3 膨閏度の測定}

既報8)と同じポリアクリロニトリルモノフィラメント に $3 \times 10^{7} \mathrm{rad}$ の電子線を照射して橋かけを生ぜしめ各 溶媒中に $30^{\circ} \mathrm{C}$ で 15 日間浸漬して重量膨潤度を既報 同様にして測定した。

\section{3. 実験結果および考察}

\section{1 溶解温度}

混合溶媒の溶解温度あるいはゲル化温度は, 高分子と 溶媒の相互作用の一つの尺度である。種々の混合溶媒の 溶解温度を Table 1 拈よび Table 2 に示す。これらの混 合溶媒は二つの群に分けることができる。その一つは混 合成分もまた, AN 重合体の溶媒である場合 (Table 1) で あり，他の一つは混合成分が AN 重合体の非溶媒である 場合 (Table 2)である。前者においては, 混合溶媒もまた 溶解性を示し, 結局全混合割合にわたって溶解性を示す。 後者では混合成分をある割合以上加えるともはや溶解性 を示さなくなり，その限界は混合成分の種類によって異 なっている。いずれの場合においても混合両成分の溶解 温度よりも混合溶媒の溶解温度が低くなることは検討し た範囲においては認められなかった。すなわち混合溶媒 の溶解温度は, 両成分単独の場合の溶解温度の中間の值 をとることが一般的傾向であった。したがって非溶媒を 混合成分として用いた場合には, 混合割合に応じて溶解 温度は高くなった。このような見地からすれば, 混合に よって溶解性を高めうるような混合成分はここで報告す る籁囲内ではないものと考えられる。

\section{2 淈厚溶夜の粘度}

前節で述べたように混合成分を加えることによって溶 
Table 1. Solution temperatures of various DMSO-other component mixed solvents (1).

\begin{tabular}{|c|c|c|c|c|c|c|c|c|c|}
\hline \multicolumn{10}{|l|}{ DMSO/Mixed component } \\
\hline $\begin{array}{c}\text { Mixed component } \\
\downarrow\end{array}$ & $9 / 1$ & \multicolumn{2}{|c|}{$8 / 2$} & \multicolumn{2}{|c|}{$6 / 4$} & \multicolumn{2}{|r|}{$4 / 6$} & & $2 / 8$ \\
\hline Dimethyl sulfone & (C) $\quad 29$ & (a) & 33 & 0 & $49 / 51$ & 0 & $63 / 64$ & & - \\
\hline Succinic anhydride & - & (a) & 63 & 0 & $75 / 43$ & O & $110 / 85$ & 0 & $142 / 135$ \\
\hline$\gamma$-Butyrolactone & - & (a) & 37 & (a) & 45 & (0) & 48 & () & 67 \\
\hline Ethylene carbonate & - & (a) & $\mathrm{R} T$ & (0) & $\mathrm{R} \mathrm{T}$ & (a) & $\mathrm{R} T$ & (2) & R T \\
\hline Acetoamide & - & (a) & 40 & 0 & $70 / 70$ & & - & $\triangle$ & 150 \\
\hline Malononitrile & - & (a) & 41 & 0 & $64 / 63$ & O & $72 / 70$ & (a) & 62 \\
\hline Propionitrile & - & (a) & 40 & (a) & 58 & (a) & 70 & (a) & 46 \\
\hline
\end{tabular}

Notice: (0): Stable polymer solution is obtained at room temp.

$O$ : The solution is stable at above the solution temperature, but not stable at room temp.

$X$ : The mixed solvent does not dissolve polymer.

$142 / 135$ means that the mixed solvent dissolves polymer above $142^{\circ} \mathrm{C}$, but phase separation occurs at $135^{\circ} \mathrm{C}$ during cooling the solution to room temp.

Table 2. Solution temperatures of various mixed solvents consisted of DMSO and other compound.

\begin{tabular}{|c|c|c|c|c|c|c|c|c|c|c|}
\hline \multirow{2}{*}{$\begin{array}{c}\text { DMSO/Mixed component } \\
\text { Mixed component } \\
\downarrow\end{array}$} & \multirow{2}{*}{\multicolumn{2}{|c|}{$9 / 1$}} & \multirow{2}{*}{\multicolumn{2}{|c|}{$8 / 2$}} & \multirow{2}{*}{\multicolumn{2}{|c|}{$6 / 4$}} & \multirow{2}{*}{\multicolumn{2}{|c|}{$4 / 6$}} & \multirow{2}{*}{\multicolumn{2}{|c|}{$2 / 8$}} \\
\hline & & & & & & & & & & \\
\hline Ethylene chlorhydrine & & - & (9) & 63 & 0 & $105 / 105$ & $x$ & & $\times$ & \\
\hline Tetrachlorethane & & - & (a) & 50 & 0 & 110 & $x$ & & $\times$ & \\
\hline Chloroform & (a) & 47 & (C) & 65 & $x$ & & $\times$ & & $\times$ & \\
\hline Furfural & & - & (2) & 25 & (a) & 25 & 0 & 65 & 0 & 70 \\
\hline Ethylenecyanohydrine & & - & (a) & 22 & 0 & $147 / 146$ & 0 & $160 / 158$ & $\bigcirc$ & $165 / 164$ \\
\hline Ethyl alcohol & (2) & 30 & (C) & 60 & $\times$ & & $\times$ & & $\times$ & \\
\hline Butyl alcohol & (a) & 30 & (a) & 50 & $x$ & & $x$ & & $x$ & \\
\hline Ethylene glycol & (a) & 52 & (2) & 62 & $x$ & & $\times$ & & $x$ & \\
\hline Acetone & & - & (c) & 25 & (a) & 35 & (0) & 45 & $\times$ & \\
\hline Cyclopentanone & & - & (a) & 30 & (a) & 30 & (a) & 53 & 0 & 85 \\
\hline Formic acid & & - & 0 & 97 & $x$ & & $x$ & & $x$ & \\
\hline Butyl acetate & (0) & 50 & (C) & 39 & (a) & 63 & $x$ & & $x$ & \\
\hline Tetrahydrofurane & & - & (C) & 69 & (2) & 58 & (a) & 57 & $x$ & \\
\hline Dioxane & & - & (a) & 40 & (2) & 42 & (a) & 83 & $x$ & \\
\hline Propylene carbonate & & - & (a) & 80 & $x$ & & $x$ & & $x$ & \\
\hline Phenol & & - & (C) & 40 & 0 & $125 / 100$ & $\times$ & & $x$ & \\
\hline Formamide & (c) & 42 & 0 & $72 / 64$ & $\times$ & & $\times$ & & $x$ & \\
\hline Toluene & (a) & 43 & (a) & 49 & (a) & 55 & $\times$ & & $x$ & \\
\hline Xylene & & 29 & (C) & 30 & 0 & $41 / 41$ & $x$ & & $x$ & \\
\hline Water & 0 & $73 / 53$ & $x$ & & $x$ & & $\times$ & & $x$ & \\
\hline
\end{tabular}

解温度は高くなり, 溶解状態はそれに応じて変化する。 しかし, 若干の混合溶媒系においては相当広、組成範围 にわたって常温において安定な溶液が形成されることが 見出されている。したがってこれらは奉用上意味のある
混合溶媒柔である。筆者はこのような混合溶媒について の溶解性についての知見を得るために, そのらちの数種 のもの, すなわちフェノール, 四塩化ェタン, テトラヒ ドロフラン, アセトン, アセトニトリル, シクロペンタ 
Table 3.

\begin{tabular}{|c|c|c|c|c|c|}
\hline \multirow{2}{*}{ Mixed component } & \multicolumn{4}{|c|}{$\eta_{0}$ (poise) $\left(40^{\circ} \mathrm{C}\right) \Delta S$} & \multirow{2}{*}{$\begin{array}{l}\text { Weight swelling } \\
\text { ratio }\end{array}$} \\
\hline & After $3 \mathrm{hr}$ & After $144 \mathrm{hr}$ & After $3 \mathrm{hr}$ & After $144 \mathrm{hr}$ & \\
\hline Phenol & 2.85 & 2.91 & 0.0081 & 0.0121 & 30 \\
\hline Tetrahydrofuran & 2.17 & 2.45 & 60 & 75 & 25 \\
\hline Tetrachlor ethane & 2.00 & 2.67 & 15 & 23 & 33 \\
\hline Acetone & 1.89 & 2.43 & 49 & 51 & 35 \\
\hline Acetonitrile & 1.67 & 2.67 & 55 & 78 & 39 \\
\hline Cyclopentanone & 2.80 & 2.00 & 139 & 109 & 43 \\
\hline$\alpha$-Pyrrolidone & 2.78 & 3.17 & 78 & 64 & 40 \\
\hline Succinonitrile & 2.67 & 2.60 & 114 & 70 & 42 \\
\hline Ethylene carbonate & 2.74 & 2.67 & 78 & 90 & 46 \\
\hline- & 2.32 & 2.26 & 61 & 47 & 57 \\
\hline
\end{tabular}

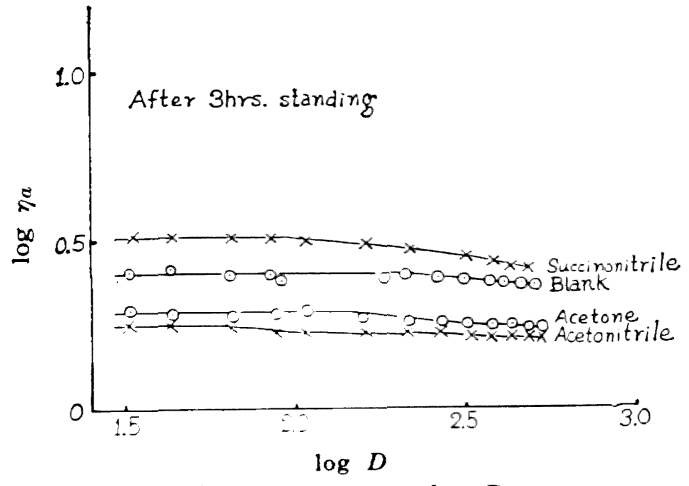

Fig. 1. $\log r_{a}$ vs $\log D$

ノンを選んで娭討した。一方混合組成の全域にわたって 溶解性のある采として $\alpha$ ピロリドン, サクシノニトリ ル，エチレンカーボネートを選んで検討した。ずれの速 度 $(D)$ およびずれ応力の範囲はそれぞれ〜 $500 \mathrm{sec} \cdots \cdots$ 小 よび 1000 dyne $/ \mathrm{cm}^{2}$ …...であるが,ずれ速度がこの程度 の場合には $r_{a}$ のずれ速度依存性はきわめて小さくいず れの場合も $D$ が約 $100 \mathrm{sec}$ 以下の場合には $\gamma_{a}$ (みかけの 粘度) はほぼ一定で $\gamma_{0}$ にほほ等しい(Fig. 1)。しかしす べての場合 $D$ がさらに大きくなるにつれて少しずつ $\eta_{a}$ の低下がみられる。 $D$ と $S$ の関倸も直線関倸からややず れる。各混合系(混合割合は、ずれも $10 \mathrm{vol} \%$ )について 得られた $\Delta S$ および Table 3 に示す。重量膨潤度の值も併記した。

溶解温度の值, 溶解性のある限界混合組成およぴ重量 膨潤度などから, 混合溶媒の溶解力は Table 3 の上から 下へいくに従って大きくなっているものと考えられる。 全混合組成にわたって溶解性を示す采におらてては $\gamma_{0}$ は DMSO 単独の場合よりも大きくなりその経時変化も比 較的小さく安定である。混合溶媒の粘度の值が求められ
ていないので $r_{0}$ の增大から，直ちに分子がより伸びた 状態への変化を示すものとの断定はできないが,これら の場合にJSもまた比較的大きい值を示し, 重合体相互 間の相互作用の増大による非ニュートン性の増大を示す ものと考えられることは $\eta_{0}$ の增大と関連つけられうる と考えられる。

これに対してアセトン, アセトニトリル, 四塩化ェ夕 ンなどでは $r_{0}$ がブランクよりも小さい。これは重合体 分子がよりまるまった状態で相互作用が小さくなった状 態に対応すると考えられ，JS もまた小さくなっている。 したがって, これら混合溶媒の場合の低粘度は溶解性の 向上を示すものではなく, 貧溶媒化の傾向を示すもので あろう。 $\eta_{0}$ の安定性はこれらの場合に良くなく，一週間 放置で相当大きい粘度上年が認められることはさらに賮 溶媒化を示すものといえよう。同時に」S も増加がみら れる。テトラヒドロフラン, フェノールなどでは溶解性 が小さいにもかかわらず $\gamma_{0}$ が大きくなっているが，こ れはさらに貧溶媒化のために重合体相互間の作用が大き くなることを示すものと考えられ, 同時にこのことは $1 S$ の值の増大としても示されている。これらの場合はゲル 化に近い溶解状態での粘性挙動に対応するものと考えら れる。

付 記：本研究に対して終始ご指導をたまわり，かつ発表 を許可された常務取楴役星野孝平博士, 技術研究部长小林治男 博士および主任研究員渡辺正元博士に梁く感謝する。

\section{文献}

1) 片山将道：高分子学会昭和 33 年年次大会研究発表 会講演 (東京, 5.31 )

2) 小野木：“レオロジー要論”23(1959)

3）高橋正夫，篠原康夫，渡辺正元：高化， 16, 720 (1959)

4) 高橋正夫, 渡辺正元：繊学誌，16, 628(1960) 


\title{
Solvent Action of Mixed Solvent Containing Dimethyl Sulfoxide as a Constituent on Acrylonitrile Polymer
}

\author{
By Masao Takahashi*
}

The solution temperatures of the mixture of dimethyl sulfoxide and the liquids which have solvent action on acrylonitrile polymers lies between those of each components. However, this temperature of the mixture of dimethyl solfoxide and the non-solvent increases proportionally with the content of non-solvent.

There were many cases where the concentrated solutions of acrylonitrile polymers in mixed solvents show lower viscosity than that in dimethyl solfoxide. These mixed solvents had lower solvent action, and the solution showed decreased stability of viscosity on standing and decreased non-Newtonian behavior. As the solvent action of mixed solvent becomes still lower, the viscosity increases again and the non-Newtonian behavior of solution shows remarkable non-Newtonian behavior.

* Research Department, Toyo Rayon, Co., Ltd (Ishiyama, Otsu, Shiga) 